\title{
Trends in Undergraduate Program Curriculum Frameworks
}

\author{
Mohammed Ali Shallal
}

Scientific Research and Development Centre, Nawroz University, Kurdistan Region, Iraq

\begin{abstract}
The paper outlines some trends in current frameworks of undergraduate (UG) academic programs, necessitating a fresh look into many local higher education institutions (HEIs) curricula with improvements and reforms in mind. An attempt is made to establish a link between national qualifications frameworks (NQFs) and academic accreditation standards to guide in the process. Focus is on two currently common issues : first, the role of NQFs and second, the adoption of specialization streams in the structure of UG program curricula. Particular attention is given to revising curricula to include general education (GE) and concentration components, within outcome-based education (OBE) environments, in a systematic manner as a way of meeting the demands. Model frameworks that may be adapted for UG programs are proposed based on current practices in many established and accredited UG program curricula to illustrate the intents.
\end{abstract}

KEYWORDS : Nawroz University (NZU), Curriculum, Outcome-Based Education, General Education, National Qualifications Framework, Academic Accreditation.

\section{Introduction}

"The learning expectations for qualifications go well beyond simple acquisition of knowledge. Numerous studies in countries throughout the world have shown strong demand for a much wider range of learning outcomes. These include personal characteristics such as honesty and reliability, capacity to work effectively in groups and provide leadership, a wide range of thinking and problem solving skills, ability to communicate effectively with different types of audience, the ability to investigate new and unexpected problems using a wide range of information sources, and a commitment to lifelong learning to make it likely that graduates will keep pace with the extremely rapid and accelerating development of new knowledge in their field" [1].

As HE continues to evolve, academic program curriculum types have diversified with new ideas of teaching and learning (T\&L) methodologies emerging to accommodate the changes required in response to three main factors :

First, the widespread incorporation of OBE approaches in the T\&L processes involving the adoption of learning

Academic Journal of Nawroz University

(AJNU) Volume 7, No 3 (2018).

Received 2 March 2018;

Regular research paper : Published 20 June 2018

Corresponding author's e-mail : mashallal@hotmail.com

Copyright (O2018 Mohammed Ali Shallal.

This is an open access article distributed under the

Creative Commons Attribution License. outcomes (LOs) at various levels.

Second, the realization that learning expectations demand that graduates cover a wider range of abilities and LOs.

Third, the emergence of new fields within various academic disciplines in order to include advances in technologies, materials, systems and workplace environments.

In response to the demands of the first two factors, NQFs that describe what learners should know, understand and be able to do on the basis of a given qualification have been developed in most countries in the world. The qualification levels are commonly defined as degrees, such as associate, diploma, bachelor, master, and doctor [4.5].

The third factor has led to the increased popularity of what are generally referred to as 'concentrations', 'tracks', and 'minors' within HE program structures and curricula.

As a consequence of these factors, regular revisions of curricula have become necessary to keep up with and incorporate the new concepts and trends. Indeed, such revisions and reforms are important requirements of all academic accreditation and re-accreditation processes and standards.

This paper considers UG curriculum framework issues relevant to the bachelor qualification level with emphasis on the inclusion of two types of components :

i. GE and

ii. concentrations 
The term 'curriculum' used within the HE context can mean different things to different groups. In this paper, aspects of curriculum development that include all courses within one program are focused on, which subsequently means that curriculum and program (of study) are used synonymously. [10]

A short glossary of definitions of terms used in this paper is presented in appendix I.

The sections that follow address two main issues :

$>\mathrm{NQFs}$ and accreditation standards demands (section

2)

$>$ proposals of curriculum model frameworks (section 3)

\section{NQFs and Accreditation Standards Requirements 2.1 NQFs}

Practically all accreditation standards and criteria, as well as the general guidelines on curricula, demand that curricula at various levels in HEIs undergo regular reviews and assessments leading to subsequent development and reforms, in-line with the principal NQF elements [1] :

- Levels

- Credits

- Domains of Learning

One important aspect of reform centres on the consideration of appropriate domains of learning when designing a curriculum. The broad categories of LOs that a program is intended to develop are based on these domains which may be expressed as : $[1,4]$

- Knowledge

- Cognitive Skills

- Interpersonal Skills and Responsibility

- Communication, IT and Numerical Skills

- Practical skills involving

$\circ$ manual dexterity

$\circ$ the use of methods, techniques, processes, and tools

reflecting a strong need for a wider range of abilities and LOs.

NQFs give details on the formation of LOs for learning domains for different levels, as well as the attributes that today's graduates need to have.

"GELOs, PLOs and PEOs for a given academic degree level may be derived in light of the characteristics of graduates and learning domain descriptions specified in the NQF, when such a local national framework exists... Subsequently, accreditation standards may demand that program goals and outcomes to be consistent with the level of qualification awarded as defined in the NQF ${ }^{[3]}$. Compatibility of other components must also be observed, general education requirements for example" [9].

Based on all of these concepts and domains, the GELOs, PEOs and PLOs for a given program are established. Other elements, such as T\&L processes and CLOs, may then follow; all of which should be properly aligned as an OBE requirement, and be in line with the HEI's mission and objectives [9].

The attainment of all of these types of LOs requires that the curriculum be designed and structured accordingly.

\subsection{Accreditation Standards}

Four accreditation standards and criteria are referred to here as examples to illustrate the need to consider the various issues mentioned in the previous section, the GE component in particular : MSCHE [2], CAA [5] , AACSB ${ }^{[8]}$ and ABET [3]. Extracts from these standards, two of which are general and the other two are programmatic, are listed in Appendix II showing criteria related to issues at hand here.

The significance given to the GE component is evident from all of the accreditation standards. This is reflected through the inclusion of adequate such components in the curriculum structures of all accredited programs as an essential requirement. The next section considers the option of introducing concentration components in addition to the essential GE component.

\section{Curriculum Frameworks}

Although most curricula currently implemented in HEIs in the area may contain various components, they don't seem to be tuned or standardized or based on any certain criteria or policy within an HEI.

All academic programs are required to undergo regular curriculum reviews leading to changes or reforms in light of various factors. Two particular such aspects of reform are through the introduction of GE and concentration components into the curricula.

Concentrations (sometimes used interchangeably with tracks) allow students to focus their learning on one or more subject areas that are of interest to them. They offer a targeted way to customize their degree, and align their education with career aspirations.

Typical requirements in a curriculum framework (with or without concentrations) are generally based on the following three major components, which make up the ground for a flexible curriculum to accommodate GE and concentration elements :

- General Education requirements.

- College/Faculty requirements.

- Department requirements.

The college requirements component refers to the knowledge and skills that every student in all degree programs in the college should attain and provide a foundation on which to specialize.

Within each component, a number of courses may be set-aside as electives in order to allow students, with the guidance of their advisors, to customize their education according to their personal and career objectives. Inclusion of one, or more, free elective courses may also 
be considered as part of the total graduation requirements.

Two frameworks are proposed below, both of which are best based on semester courses and include the GE component. Both may also contain electives in the various ways :

i. A basic 3 level curriculum framework, without concentrations.

ii. A basic 3 level curriculum framework, with concentrations incorporated.

Models are chosen from two universities offering accredited UG programs to demonstrate the issues addressed in this paper, namely AAU [6] and UAEU [7].

\subsection{Curriculum Framework I :}

The first structure is based on a standard framework commonly adopted in many UG academic programs.

Table 1a and figure 1 suggest a typical structure of a framework, with the inclusion of electives in the basic curriculum components. The number of units in each component may vary from one discipline to another, depending on the accreditation standards and program criteria adopted as guidelines, but the structure of the GE component may be almost fixed within an HEI.

Table (1a) : Graduation Program Requirements : Total N Credit Hours (CrHrs)

\begin{tabular}{|c|c|c|c|}
\hline Requirements & $\begin{array}{c}\text { Compul } \\
\text { sory } \\
\text { CrHrs }\end{array}$ & $\begin{array}{l}\text { Electives } \\
\text { CrHrs }\end{array}$ & $\begin{array}{l}\text { Total } \\
\text { CrHrs }\end{array}$ \\
\hline $\begin{array}{c}\text { GE or } \\
\text { University } \\
\text { (UR) }\end{array}$ & $\mathrm{n}$ & $\mathrm{m}$ & $\mathrm{n}+\mathrm{m}$ \\
\hline $\begin{array}{l}\text { College } \\
\text { (CR) }\end{array}$ & k & & k \\
\hline \multirow[t]{2}{*}{$\begin{array}{c}\text { Dept } \\
\text { /Specializat } \\
\text { ion (DR) }\end{array}$} & $\mathrm{i}$ & $\mathrm{j}$ & $i+j$ \\
\hline & $\mathrm{n}+\mathrm{k}+\mathrm{i}$ & $m+j$ & $\begin{array}{c}\text { TOTAL } \\
\mathrm{N}\end{array}$ \\
\hline
\end{tabular}

Figure (1) : Curriculum Framework I

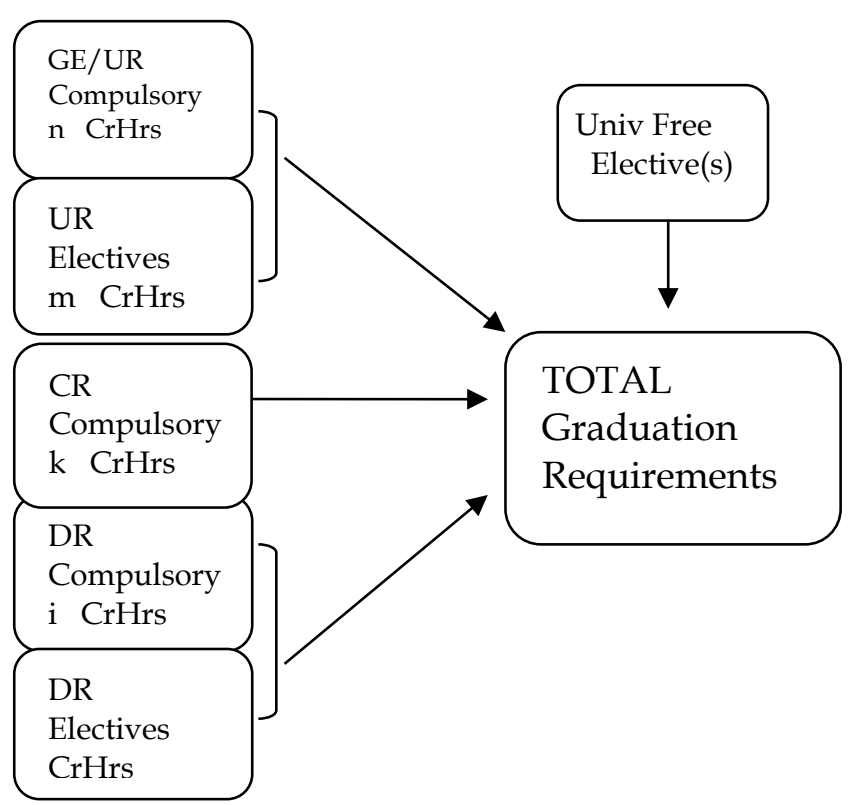

Typically, the number of CrHrs for the GE/UR component (i.e. $\mathrm{n}+\mathrm{m}$ ) constitutes about $25 \%$ of the total $\mathrm{N}$. The number of CrHrs in other components may be determined partly through the accreditation standards and criteria in addition to international curriculum guidelines specific to the program's discipline. As an example for this framework, table $1 \mathrm{~b}$ gives the number of CrHrs in each category for a set of accredited programs at AAU [6] incorporating the ideas outlined. All programs have, and may share the same CrHrs for the UR/GE component :

Table (1b)

\begin{tabular}{|c|c|c|c|c|c|c|c|c|}
\hline & Program & $\begin{array}{c}\text { GE/UR } \\
\mathbf{n + m}\end{array}$ & $\begin{array}{c}\text { CR } \\
\text { College } \\
\text { Reqrmnts }\end{array}$ & $\begin{array}{c}\text { Speclzn } \\
\text { Reqrmts }\end{array}$ & $\begin{array}{c}\text { Supporting } \\
\text { Reqrmts }\end{array}$ & $\begin{array}{c}\text { Internship, } \\
\text { Capstone } \\
\text { Project }\end{array}$ & $\begin{array}{c}\text { Univ Free } \\
\text { Elective p }\end{array}$ & $\begin{array}{c}\text { Total } \\
\text { CrHrs }\end{array}$ \\
\hline $\mathbf{1}$ & $\begin{array}{c}\text { Computer } \\
\text { Engineering }\end{array}$ & 33 & 24 & 70 & 7 & 6 & - & 140 \\
\hline $\mathbf{2}$ & $\begin{array}{c}\text { Computer } \\
\text { Science }\end{array}$ & 33 & 24 & 48 & 12 & 6 & - & 123 \\
\hline $\mathbf{3}$ & $\begin{array}{c}\text { English L } \\
\text { Teacher Ed }\end{array}$ & 33 & 15 & 51 & 12 & 12 & 3 & 126 \\
\hline $\mathbf{4}$ & Law & 33 & 15 & 76 & - & 5 & - & 129 \\
\hline $\mathbf{5}$ & Pharmacy & 33 & 15 & 91 & - & 21 & - & 160 \\
\hline
\end{tabular}

Notes: 
1. A credit hour is based on a formula in which one 50 minute lecture or two/three 50 minute laboratory over a 15 week teaching semester are regarded as one credit hour.

2. Only the first 2 programs in the table are from the same college (thus, they also share the college requirements ), while the other three are from different colleges.

3. The supporting requirement component, if included, may be designed to broaden students' knowledge and perspective of education, as they enhance the major.

\subsection{Curriculum Framework II :}

Experience has shown that for fields within program disciplines (i.e. majors), a common base of core courses as college requirements could be followed by concentrations where students have the option of choosing the concentration or track they desire.

Figure 2 suggests a possible framework including many of the components mentioned :

Figure (2) : Curriculum Framework II

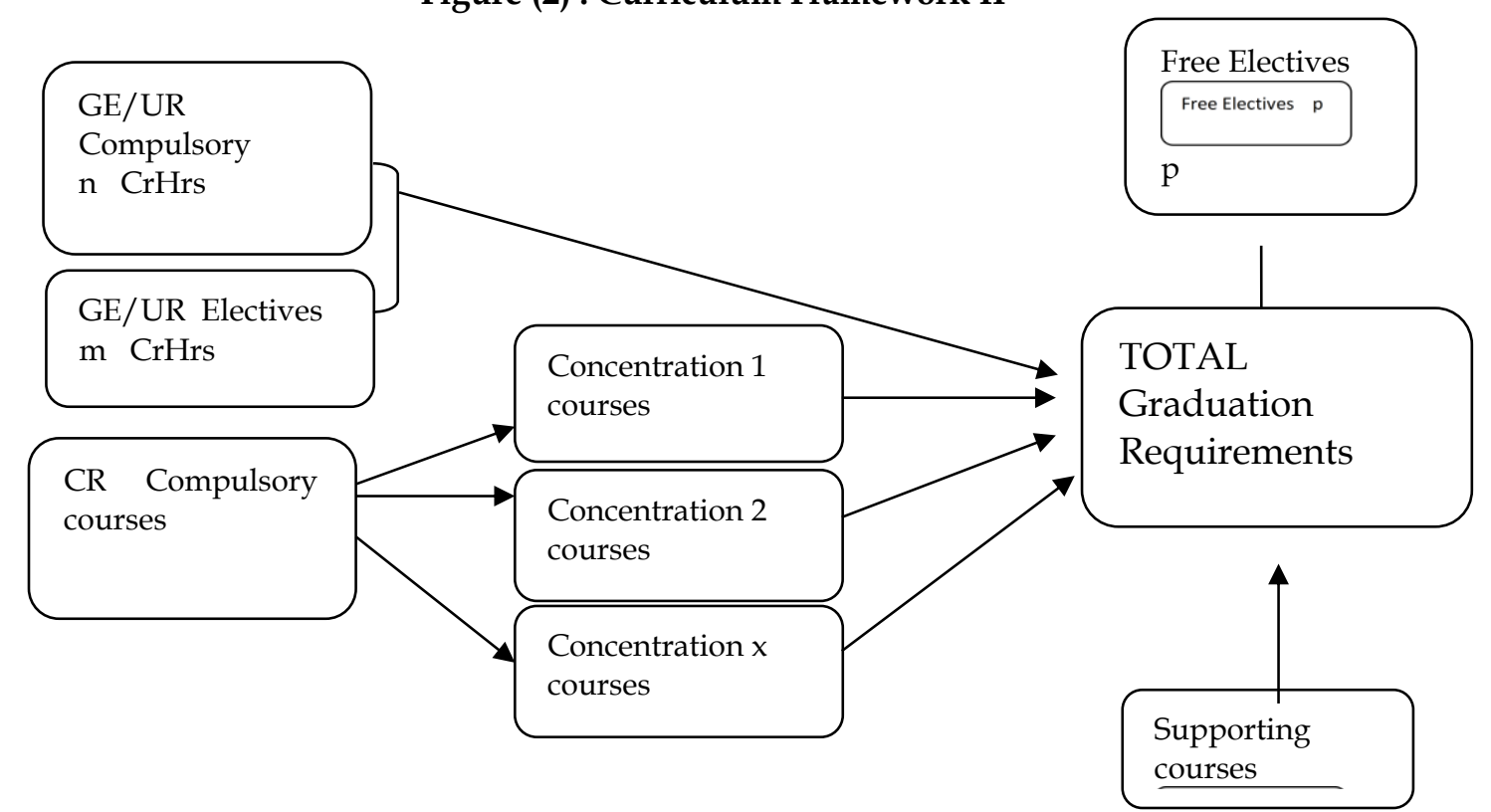

Two models, chosen as illustrations based on the above framework, are shown in tables $2 \& 3$. The first model (table 2) considers the inclusion of a number of

concentrations for a single program, a business administration bachelor degree, from AAU.

Table (2) : Bachelor in Business Administration, BBA (AAU)

\begin{tabular}{|l|c|c|c|c|c|c|c|c|}
\hline & $\begin{array}{c}\text { Specialization } \\
\text { (concentration) }\end{array}$ & $\begin{array}{c}\text { GE } \\
\text { Reqrmnts }\end{array}$ & $\begin{array}{c}\text { College } \\
\text { Reqrmnts }\end{array}$ & $\begin{array}{c}\text { Concntrn } \\
\text { Reqrmnts }\end{array}$ & $\begin{array}{l}\text { Supprtng } \\
\text { Reqmnts }\end{array}$ & $\begin{array}{c}\text { Practcm } \\
\text { Project }\end{array}$ & $\begin{array}{c}\text { Univ Free } \\
\text { Electve }\end{array}$ & $\begin{array}{c}\text { Total } \\
\text { CrHrs }\end{array}$ \\
\hline 1 & Management & 33 & 45 & 27 & 12 & 3 & 3 & 123 \\
\hline 2 & Accounting & 33 & 45 & 27 & 12 & 3 & 3 & 123 \\
\hline 3 & Finance\&Banking & 33 & 45 & 27 & 12 & 3 & 3 & 123 \\
\hline 4 & Marketing & 33 & 45 & 27 & 12 & 3 & 3 & 123 \\
\hline 5 & HR Management & 33 & 45 & 27 & 12 & 3 & 3 & 123 \\
\hline 6 & MIS & 33 & 45 & 27 & 12 & 3 & 3 & 123 \\
\hline
\end{tabular}

Notes :

1. Observe that the GE requirements are also $33 \mathrm{CrHrs}$, same as in table (1b) (all AAU).

2. All the college requirements courses in the table may be common for all the students in the college enrolled in the BBA program. Only courses in the concentration requirements column (27 CrHrs) are specific to the concentration.
The second model involves four programs, from the College of Information Technology (IT) at the UAEU, one of which (bachelor in IT, accredited by ABET) includes seven concentrations (called specialization tracks). Table 3 a shows the overall structure for the four programs, while table $3 \mathrm{~b}$ shows the specific concentrations for the IT program. 
Table (3a) : College of IT UAEU : four programs

\begin{tabular}{|c|c|c|c|}
\hline $\begin{array}{l}\text { Computer } \\
\text { Engineering }\end{array}$ & $\begin{array}{l}\text { Computer } \\
\text { Science }\end{array}$ & $\begin{array}{l}\text { Informati } \\
\text { on } \\
\text { Security }\end{array}$ & $\begin{array}{l}\text { Information } \\
\text { Technology }\end{array}$ \\
\hline $\begin{array}{l}\text { GE (42 } \\
\text { CrHrs) }\end{array}$ & $\begin{array}{l}\text { GE (42 } \\
\text { CrHrs) }\end{array}$ & $\begin{array}{l}\text { GE (42 } \\
\text { CrHrs) }\end{array}$ & GE (42 CrHrs) \\
\hline $\begin{array}{l}\text { College Req } \\
\text { (36 CrHrs) }\end{array}$ & $\begin{array}{l}\text { College Req } \\
\text { (36 CrHrs) }\end{array}$ & $\begin{array}{c}\text { College } \\
\text { Req } \\
\text { (36 CrHrs) }\end{array}$ & $\begin{array}{l}\text { College Req } \\
\text { (61 CrHrs) }\end{array}$ \\
\hline $\begin{array}{l}\text { Major Req } \\
\text { (50 CrHrs) }\end{array}$ & $\begin{array}{l}\text { Major Req } \\
\text { (40 CrHrs) }\end{array}$ & $\begin{array}{l}\text { Major Req } \\
\text { (46 CrHrs) }\end{array}$ & $\begin{array}{l}7 \text { Tracks, }(21 \\
\text { CrHrs each) see } \\
\text { table } 3 \mathrm{~b} \text { below }\end{array}$ \\
\hline $\begin{array}{c}\text { Major } \\
\text { Electives (16 } \\
\text { CrHrs) }\end{array}$ & $\begin{array}{c}\text { Major } \\
\text { Electives (12 } \\
\text { CrHrs) }\end{array}$ & $\begin{array}{c}\text { Major } \\
\text { Electives } \\
\text { (6 CrHrs) }\end{array}$ & $\begin{array}{l}\text { Specialization } \\
\text { Elective } \\
\text { Free Elective } \\
(3 \mathrm{CrHrs}) \text { each }\end{array}$ \\
\hline 144 & 130 & 130 & 130 \\
\hline
\end{tabular}

Notes :

1. The college requirements for the first three programs (36 CrHrs) is different from the IT program (61 CrHrs) because of the tracks involved in the latter.

2. The 42 GE CrHrs include senior Graduation Projects I \& II (6 CrHrs).

3. Some tracks include elective courses.

Table $(3 b):$ The seven specialization tracks in the IT program are :

\begin{tabular}{|c|c|c|c|}
\hline 1 & Track & $\begin{array}{c}\text { Req. } \\
\text { CrHrs }\end{array}$ & $\begin{array}{c}\text { Specialization } \\
\text { Electives }\end{array}$ \\
\hline 2 & $\begin{array}{c}\text { Intelligent } \\
\text { Systems } \\
\text { INSY) }\end{array}$ & 18 & 3 \\
\hline 3 & $\begin{array}{c}\text { Software } \\
\text { Development } \\
\text { (SWD) }\end{array}$ & 18 & 3 \\
\hline 4 & $\begin{array}{c}\text { Information } \\
\text { Security } \\
\text { (SEC) }\end{array}$ & 18 & 3 \\
\hline 5 & $\begin{array}{c}\text { Networking } \\
\text { (NETW) }\end{array}$ & 18 & 3 \\
\hline 6 & $\begin{array}{c}\text { E-Commerce } \\
\text { ECOM) } \\
\text { System } \\
\text { (ENSYS) }\end{array}$ & 21 & 3 \\
\hline 7 & $\begin{array}{c}\text { Computer } \\
\text { System } \\
\text { Design } \\
\text { (CSD) }\end{array}$ & 18 & \\
\hline
\end{tabular}

Other frameworks based on different combinations of components described in this paper may be constructed and may be found in the literature.

\section{Summary, Conclusions, and Recommendations}

Curriculum revision is an important part of academic work. ${ }^{[11]}$ The paper has attempted to raise awareness to the fact that many local curricula require a fresh look into their frameworks targeting reforms in-line with the current trends in light of international guidelines and accreditation standards.

The following are some conclusions and recommendations :

a. Current market and industry requirements from graduates clearly point to the necessity of reviews incorporating OBE and student centred learning (SCL) processes with the necessity of addressing alignment of the various components involved.

b. Academic curricula in many programs in HEIs in the area need to be revised and reformed in light of NQFs and accreditation standards' requirements. Without such reforms, meaningful program self assessment reports cannot be obtained, and will render any future academic accreditations efforts doubtful.

c. It is essential to keep in touch with trends and innovations through regular reviews and benchmarking against accreditation standards and frameworks of UG academic programs in HEIs elsewhere, necessitating improvements and reforms and allowing the timely update of the individual components of the curriculum. d.Consider the establishment of a GE Division/Unit central to all programs at the HEI. Such a unit is to be responsible for developing, teaching, assessing, and improving the courses required for the GE component of the curriculum.

e. Adoption of a curriculum structure based on semester courses, as institutionally recognized units of study, is recommended. Such a structure would add a degree of flexibility for modification and help in the ongoing process of curriculum development.

f. Provide the requirements for the introduction of electives, concentrations, tracks and minors into the curricula. Such steps will give students the ability to have a say in choosing the streams they desire, as well as accommodating the diversity in the emerging fields within majors and paving the way for interdisciplinary teamwork, among other advantages.

g. Establish policies and procedures for the development of plans, teams, and working committees to achieve the processes needed for the purposes addressed in this paper.

\section{Acknowledgments}

Key concepts underpinning various views on curriculum development in this paper were identified from the literature ${ }^{[1-14]}$. Seminars and workshops held at NZU in related fields helped in enriching the material presented [12]. 


\section{References}

1.National Qualifications Framework for Higher Education in the Kingdom of Saudi Arabia, May, 2009

2.MSCHE, Middle States Commission on Higher Education, Standards for accreditation and requirements of affiliation, http : / /www.msche.org

3. ABET EAC, CAC, Accreditation Board for Engineering and Technology, http : //www.abet.org 4. Extracts from the Qualifications Framework Handbook (QFEmirates, http : / / www.caa.ae

5.CAA, Commission for Academic Accreditation, http : //www.caa.ae

6. Al Ain University of Science \& Technology, http : //www.aau.ac.ae

7.United Arab Emirates University, http : //www.uaeu.ac.ae

8.AACSB, The Association to Advance Collegiate Schools of Business, www.aacsb.edu

9. Mohammed Ali Shallal, "Alignment of Curriculum Elements at the Course Level : Two Useful Tools", Academic Journal of Nawroz University (AJNU) Volume 7, No 3, 2018.

10. Nicole Totté, Steven Huyghe \& Alexandra Verhagen, "Building the curriculum in higher education : a conceptual framework", Academic Development Unit, KU Leuven, Belgium

11. G. O'Neill, "Initiating curriculum revision : exploring the practices of educational developers", International Journal for Academic Development, vol 15 , no 1,2010

12. Academic Program Curriculum Frameworks, Seminar, Nawroz University, Jan 2018

13. Curriculum Guidelines for UG Degree Programs in Computer Science, ACM, IEEE Computer Society, December 2013

14. Report in the Computing Curricula Series, Joint Task Force on Computer Engineering Curricula, ACM,IEEE, CE2016

\section{APPENDIX I Glossary (Compiled From Various Sources)}

(Other definitions/interpretations may be found depending on the source/context assumed)

CLO : course learning outcome, a statement of what learners are expected to be able to do on successful completion of the course in order to demonstrate their knowledge, understanding, skills and/or competences.

Concentrations : are best thought of as a grouping of courses which represent a subspecialization taken within the major field of study. For example a student majoring in biology might have a concentration in genetics. A concentration may be specified on the student's degree certificate. The CAA requires a concentration to include at least 15 semester credits of study, or equivalent, in the specialized field. The words concentrations and tracks are sometimes used interchangeably.

Electives : Courses which are not compulsory for students. Electives may be free-selected by the student from any course offerings, or restricted - chosen from a pre-determined list of options.

General Education : is that aspect of the curriculum intended to provide students with critical thinking skills; a broad understanding of the approaches to knowledge such as the humanities, the arts, the social sciences or the sciences; a common core of understanding among students (such as cultural studies); and a level of skill appropriate to higher education in mathematics, information literacy, the application of technology and communications (oral and written).

GELO : at the institution level, general education LO (also called ILO : Institutional LO), knowledge and/or skills that all graduates should attain, regardless of the program.

Major : A cohesive combination of courses including introductory, intermediate, and advanced coursework that designates a student's primary area of undergraduate study. A major is typically $36-76$ credit hours. Majors can be restructured to include required or optional tracks/ concentrations.

Minor: A minor is a separate field of study outside the major or concentration in which a student has a secondary area of specialization, requiring less course work than the major. Minors usually require that students earn 12-18 semester credits in subject area courses.

OBE : outcome based education, a method of curriculum design and teaching that focuses on what students gained and actually do after they are taught.

PEO : program educational objective, a broad statement that describes what graduates are expected to attain within a few years of graduation.PEOs are based on the needs of the program's constituencies. (ABET)

PLO : program learning outcome, is a statement of what learners are expected to know, understand or be able to do on successful completion of the entire program.

SCL: an environment where students are responsible for their own learning and engagement of both students and lecturer are visible

Semester : A semester is a period of time, typically a minimum of 15 weeks, during which an institution offers courses.

Semester credit : 1 semester credit hour is based on a formula in which one 50 minute lecture or two/three 50 minute laboratory over a 15 week teaching semester are regarded as one credit hour. 


\section{Appendix II Extracts from Accreditation Standards}

A. CAA, Commission for Academic Accreditation (general standards, not specific to any program discipline)

i. Criterion 3.1.3 requires that each academic program has well-articulated program goals and outcomes which are consistent with the level of qualification awarded as defined in the UAE NQF.

ii. Criterion 3.2.1 requires that the curriculum of each academic program comprises a progression and mix of courses (such as major, concentration, GE, and electives).

iii. Criterion 3.4 requires that the institution ensures that all students in UG programs requiring two years or longer of fulltime study complete a broadly based general education requirement designed to add breadth to students' intellectual experience, in various areas such as languages, humanities or arts, natural sciences, information technology (IT) or mathematics, social or behavioral sciences, culture, oral and written communication in the language of instruction, and critical reasoning.

B. MSCHE : Middle States Commission on Higher Education, US ( general standards, not specific to any program discipline)

" Standard III An accredited institution possesses and demonstrates the following attributes or activities :

5. at institutions that offer undergraduate education, a general education program, free standing or integrated into academic disciplines, that :

i. offers a sufficient scope to draw students into new areas of intellectual experience, expanding their cultural and global awareness and cultural sensitivity, and preparing them to make well-reasoned judgments outside as well as within their academic field;

ii. offers a curriculum designed so that students acquire and demonstrate essential skills including at least oral and written communication, scientific and quantitative reasoning, critical analysis and reasoning, technological competency, and information literacy. Consistent with mission, the general education program also includes the study of values, ethics, and diverse perspectives; and

iii. in non-US institutions that do not include general education, provides evidence that students can demonstrate general education skills; "

C. AACSB, The Association to Advance Collegiate Schools of Business (programmatic)

All general management and specialist degree programs would normally include learning experiences that address the following general skill areas and general business and management skill areas :

- Written and oral communication

- Ethical understanding and reasoning
- Analytical thinking

$\cdot$ IT

- Interpersonal relations and teamwork

- Diverse and multicultural work environments

- Reflective thinking

- Application of knowledge

D. ABET, Accreditation Board for Engineering and Technology (programmatic)

D1. EAC (Engineering Accreditation Commission) : Criterion 5. Curriculum

"The faculty must ensure that the program curriculum devotes adequate attention and time to each component, consistent with the outcomes and objectives of the program and institution. The professional component must include :

- a broad education component that complements the technical content of the curriculum and is consistent with the program educational objectives."

D2. CAC (Computing Accreditation Commission) : Criterion 5. Curriculum

“The program's requirements must be consistent with its program educational objectives and designed in such a way that each of the student outcomes can be attained. The curriculum must combine technical and professional requirements with general education requirements and electives to prepare students for a professional career and further study in the computing discipline associated with the program, and for functioning in modern society." 